\title{
Leadership Training In An MBA Program Using Peer-led Team Learning
}

Gregory Dobson, University of Rochester, USA

Robin Frye, University of Rochester, USA

Ravi Mantena, University of Rochester, USA

\begin{abstract}
Leadership training is an important part of any MBA program, but is often difficult to provide in an effective way. Over the last three years, we implemented a program of Peer-Led Team Learning in two core courses of our MBA curriculum, which we believe provides a good solution. The program combines leadership training with practical hands-on application of the ideas taught, and provides for an effective feedback loop. Response to the program has been overwhelmingly positive. The program and benefits for learning leadership are discussed in this paper.
\end{abstract}

Keywords: Workshop Model; Leadership Training; Peer-Led Team Learning; Active Learning

\section{INTRODUCTION}

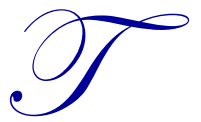

eaching innovations in undergraduate and graduate education are nothing new. The spread of teaching and learning centers across the country at many colleges and universities demonstrates this. Active learning, which engages students in the learning process, is often the centerpiece of new and popular methods (for example, Svinicki \& McKeachie, 2010; Fink, 2002; Bain, 2004; Bean, 1996). An especially salient active learning technique is the use of student peers as mentors, facilitators, and leaders (for example, Libarkin \& Mencke, 2001, 2002; Triesman, 1992; Sawada et al., 2002; Platt, Roth and Kampmeier, 2003). Peer-led team learning is one such practice that has been used successfully in the U.S., particularly in the Northeast, with undergraduates for over a decade (Tien, Roth \& Kampmeier, 2002 and 2004; Platt, et al, 2008). The model is incorporated widely and very successfully on the University of Rochester campus, principally in large undergraduate lecture courses, including Chemistry and Biology. The program has been so successful that it has expanded over the years to include a wide variety of courses such as Optics, Computer Science, Physics, and Philosophy, among others. While the main goal of this approach is to improve student learning with difficult subject material, peer leaders have consistently and repeatedly reported considerable positive benefits of being a peer leader (Gafney \& Varma-Nelson, 2007). MBA programs, which emphasize the development of future business leaders, seem ideally suited for such a model.

In their extensive study of business education, Datar, Garvin \& Cullen (2010) argue, quite cogently, that business education is at a crossroads. Based on interviews with business school deans, executives and MBA students, they conclude that in order to remain relevant, business education needs to emphasize the development of leadership skills and more broadly utilize new pedagogies, including hands-on or experiential learning. Peer-led team learning, which we refer to as the Workshop Model, has the potential to achieve both of these goals. Weekly workshop sessions are interactive by design and workshop leaders develop leadership skills by attending weekly leadertraining seminars and immediately putting the ideas into practice leading the weekly workshops.

\section{A Brief History Of The Workshop Model}

The Workshop Model is an effective, research supported learning and teaching practice (Roth, Goldstein, \& Marcus, 2001; Gosser, et al, 2001). Workshops are course specific problem-solving sessions comprised of small groups of students who are led by a specially trained peer leader. The peer-led workshop is an interactive, collaborative learning team that works together each week to solve challenging problems related to the course 
content. Student leaders are carefully chosen and trained by faculty and learning specialists in course content, group dynamics, the basics of learning theory, and diversity issues. Workshop materials are designed to build conceptual understanding and problem-solving skills and to bridge the gap between the textbook and the real world. In the model, faculty members are closely associated with workshop activities and student leaders. To date, the Workshop Model is used most frequently in undergraduate science and math courses. Business education, we believe, is an ideally suited next step for this model.

\section{Workshops in MBA Education: A New Initiative}

Our initial motivation for introducing the Workshop Model into two core MBA courses was to improve student engagement and learning, in particular to improve students' ability to solve problems involving modeling business situations that differed from the standard, introductory ones they saw in the lectures. We were particularly interested in improving their ability to think about realistic business problems and abstract from them in such a way as to apply the models discussed in class. Our choice of trying the peer-led Workshop Model as a means to our goal was easy. First, it is already used widely and effectively at our University, so a system was already in place for us to build on. Second, these kinds of complex business problems lend themselves well to exploration in a collaborative setting, and third, the model had the added benefit of developing student leaders, a core goal of our mission. While leadership experience is essential for business executives, directly teaching leadership has often been overlooked in MBA education (Datar, Garvin \& Cullen, 2010). The Workshop Model builds leadership skills through selfreflection, small group discussion, peer feedback and, of course, hands on experience. Finally, the emphasis on working in teams fits right into our program and the growing demand for teamwork in the business world (e.g., Lencioni, 2005; Katzenbach, Smith \& Smith, 2001; Offerman \& Spiros, 2001; Cohen \& Barley, 1997). Going forward, to avoid confusion, we reserve the term student for those students taking the core MBA classes, leader for those students who were the peers leading the students, workshop, for the problem-solving sessions that the leaders ran, seminar for the weekly leader training sessions, and instructor, for the faculty running the core classes and for the learning specialist running the seminar.

As stated earlier, there is a small but growing trend in business education, in the last decade or so, advocating the teaching of leadership, especially authentic leadership (Bennis, 2009; Endrissat, Muller \& KaudelaBaum, 2007; George, 2004; George, Sims \& Gergen, 2007; Ladkin \& Taylor, 2010; Roche, 2010, Shamir \& Eilam, 2005, Datar, Garvin \& Cullen, 2010) and towards experiential, team learning (Yazici, 2005; Gardner \& Korth, 1998; Robbins, 1994; Miglietti, 2002; Lancaster \& Strand, 2001). By adding peer-led workshops and an accompanying leader-training course, the seminar, we are addressing both goals. While we are tracking student learning through grades, course evaluations and midterm surveys, we are simultaneously tracking the leader experience as well.

The Workshop Model is a unique leadership experience in a number of ways. First, it provides leaders with an opportunity to learn a new skill, practice that skill, reflect individually on the implementation of that skill via a journal, and finally to discuss their success or difficulty with implementing that skill with the other leaders in the weekly seminar. Second, built into the program is a mechanism for giving and receiving feedback about one's leadership behaviors. Every workshop group gives anonymous feedback to its leader through a midterm feedback questionnaire, which is thoroughly discussed with the leaders. This process allows leaders to review their individual feedback and compare it to the group averages. Finally, all the leaders experience and discuss the same course workshop problems each week with their fellow leaders. Contrast this with a situation where leaders might gather to discuss their personal work or project experiences which are completely distinct. Without the common experience it is challenging to comprehend, let alone compare or discuss, techniques and approaches for improving their effectiveness as leaders. Further, even if one were able to glean an insight from another's experience, there is no immediate opportunity to apply it. Finally, the workshop problems are a part of the core course material, which the leaders are already quite competent in, and have discussed thoroughly in the weekly seminar. Thus, they can focus on the skills to lead their groups without being significantly distracted by the content of the problems their groups are trying to solve.

To our knowledge this is the first time that peer-led team learning has been implemented in an MBA program. As such, we will begin by describing the program in more detail. After 8 terms of running the program, we are strongly encouraged by positive feedback from our leaders. This report documents that feedback, highlighting 
the strengths of the program, curricular concerns, and organizational particulars. Overall, we conclude that the model is a valuable method for incorporating leadership development into our MBA program.

\section{WORKSHOPS IN THE SIMON SCHOOL MBA PROGRAM}

The Workshop Model was first implemented at the Simon School of Business at the University of Rochester in 2009 for two core courses in our full-time MBA program - Framing and Analyzing Business Problems (GBA411, a course that introduces probability, statistics, and optimization via spreadsheet modeling of business problems) and Operations Management (OMG402, a course that takes a process centric view of business systems and explores the implications of variability for those systems). Both courses are required for all first-year MBA students and, prior to implementing Workshops, had included T.A.-led recitations. The initiative started with a pilot implementation of the program in two sections - one of each course in the Winter and Spring Quarters of 2009 for a single cohort of MBA students. The following year, 2009-2010, we expanded the initiative to include workshops in all sections of GBA411 and OMG02 and it has since become a standard part of these two courses in our full-time M.B.A. program.

Over the last three years, three different professors have been involved with this program - one for the OMG course, and two for GBA. Regardless of professor, or course, the structure and implementation of the program have remained similar over the three years. Naturally, the content of the Workshops (in terms of the actual problem sets used) has varied depending on course and professor preferences, but even these have been similar in length, complexity and design. Further, the learning specialist, the person responsible for organizing and instructing the pedagogy component of leader training, has remained the same throughout, and has largely maintained the same curriculum for these sessions.

There are two main components of the Workshop Model. First, there are the peer leaders who take the leader-training seminar and second, there are the workshops where the leaders facilitate a problem-solving session. In the next sections, we will describe these components in more detail.

\section{The Peer Leaders}

During the period from January 2009 to May 2011, 66 leaders facilitated a total of 117 Workshop groups. Many of our leaders volunteered to lead multiple workshop groups in the same quarter and participated in the program for more than one quarter (a point that will be addressed in greater detail later). Our leaders were mainly second-year MBA students; however, we did have a large proportion of first-year students during the first year of implementation and three who were first-year students during the 2009-2010 academic year. Whether first- or second-year, all students served as leaders only after completing the course in which they were to facilitate a workshop. In the first year of implementation (winter and spring, 2009) none of the leaders had participated as a student in a workshop, however, by the following year (2009-2010) all had. In one term, three of our leaders were also students in another course using workshops during the same term.

The full-time MBA students at Simon come from all over the world representing 16 different countries. The average age of our full-time MBA students is 25 . Our 66 leaders were representative of the general population at Simon: 46 males, 20 females; 23 native to US, 24 from India or the Middle East, 19 from other countries including Mexico, Africa, Japan, and China. Our leaders were slightly older than our average full-time MBA student.

Each spring, leaders are selected for the following academic year through a rigorous group interview process. During the interview, applicants sit around a table and discuss challenging scenarios that could arise in the workshop setting, while the interviewers remain mute observers. As selectors, we are not as interested in 'correct' answers as in an attitude demonstrating an openness regarding the various issues. Furthermore, we observe their behaviors towards each other to judge their instincts for handling group discussions. Typically, more students apply to be a leader than we have positions for. For example, this past year, 54 students applied for 32 positions. The learning specialist, the professors, and several of the current leaders contribute to the selection process. The completed application, interview performance, and academic performance in the target course are all important components of the selection process. Our main goal here is to select leaders who are high performers in terms of the 
content material, are open to learning about leadership, and are keenly interested in improving their leadership skills. Their current leadership skills, as demonstrated in the interview, are less crucial.

\section{The Leader-Training Seminar}

The seminar is a zero-credit course that all leaders are required to attend. Leaders are paid a stipend to lead their weekly workshop sessions. The popularity of the program is especially noteworthy because there is no course credit. Altogether, leaders devote about 6 to 7 hours per week, which includes the time spent in seminar, prepping for the seminar, the time spent in the workshop, and the time writing the journal reflecting on the workshop. Upon completion of the seminar, all leaders receive a letter of commendation from the dean in the form of a certificate. The seminar meets weekly for an hour and a half with the exception of the first week where we meet three times to front-load the material on leadership. Expectations for the seminar include weekly pre-seminar assignments (usually reading an article or listening to an audio clip), writing weekly journals and, of course, attending the seminar. About half of the seminar time is used for discussing leadership and facilitation topics such as group dynamics, motivation, diversity and learning theory. The other half of the time is used to discuss the course problems for the workshop for that week and coming up with specific strategies and techniques to use in the workshops.

We devote the first few sessions to pedagogy because a major purpose of the peer-led workshop is to increase active learning on the part of the students assigned to workshops. A very important pedagogical technique that we emphasize, for example, is reflective or reciprocal questioning. Prior to class, leaders read an article about reciprocal questioning (more or less a "how to" guide). In class, we discuss specific reciprocal questions that leaders could ask and we practice this technique using the material for the workshop that week. Later in the term we have a session on micro-aggressions. Micro-aggressions are small slights people may experience based on any number of reasons including gender, race, sexual orientation, religion or disability. After reading an article and listening to a short audio clip, student leaders will think and write about a micro-aggression that they've personally experienced or witnessed. We discuss possible ways they may encounter micro-aggressions in their workshops and in any other area of life. We also discuss effective ways to respond to such incidents. Table 1 outlines a typical, and more complete, schedule of topics covered in the leader training seminar, the associated readings, and class activities.

\section{The Workshops}

Workshops are held each week after the seminar. The carefully trained leader does not supply answers or give lectures; instead, he or she is instructed to guide the students towards completing the problems together. The weekly problem set is distributed at the start of the workshop and no answer key is ever provided. The philosophy of the program is that the workshop simulates real life: there are no answers at the back of the book when your business is confronted with a new problem. While we never give out answer keys, peer leaders are expected to understand the problems well enough to guide their students on the path to solving them. In many weekly sessions, for example, leaders let their students make mistakes by going down a wrong path in solving a problem. This is an important part of the learning process (e.g., Kornell, Jensen and Bjork, 2009; Cyr and Anderson, 2011). Leaders step in when students are far off-track, very confused, or need to be mindful of the time constraint (See Roth, Goldstein \& Marcus, 2001, for more information about the model.). When leaders do step in, however, it is usually not with answers or clear-cut direction. Instead they may ask reflective questions to get the group thinking in more productive ways, encourage students to represent the problem in different ways, or facilitate discussion between students locked in unproductive conflict.

Leading a workshop is different from serving as a leader of an organization, committee, or other group in the "real" world. Workshop leaders do know the answers to the problems their groups are working to solve, whereas most groups outside of an academic setting do not know the solution to the problem in advance. We think that this presents a unique learning opportunity for our leaders. They can focus on developing leadership skills such as managing different types of personalities (e.g., drawing out the quiet types or quieting the verbose types), increasing their sensitivity to multicultural and diversity issues (e.g., recognizing differing views regarding authority figures), and developing their own personal leadership style. In addition, they can concentrate on time management without having an uncertain endpoint because they have a limited problem set. 
Table 1: A Typical Plan for Leader Training Sessions

\begin{tabular}{|c|c|c|c|}
\hline Topic & Materials & Class Activity & Workshop Application \\
\hline $\begin{array}{l}\text { Leadership: Meaning } \\
\text { and Styles }\end{array}$ & $\begin{array}{l}\text { Kouzes \& Posner (2001) } \\
\text { Bringing Leadership Lessons } \\
\text { from the Past to the Future }\end{array}$ & $\begin{array}{l}\text { Four small groups discuss each } \\
\text { of the four lessons, then groups } \\
\text { share with each other }\end{array}$ & $\begin{array}{l}\text { Students reflect on their own } \\
\text { leadership style and what they } \\
\text { wish to accomplish }\end{array}$ \\
\hline $\begin{array}{l}\text { Cognitive } \\
\text { Apprenticeship }\end{array}$ & $\begin{array}{l}\text { Collins (2002) Cognitive } \\
\text { Apprenticeship }\end{array}$ & $\begin{array}{l}\text { The cognitive apprenticeship } \\
\text { model and its application are } \\
\text { discussed }\end{array}$ & $\begin{array}{l}\text { Leaders apply the model to } \\
\text { Workshops }\end{array}$ \\
\hline $\begin{array}{l}\text { Reflective/ } \\
\text { Reciprocal Questioning }\end{array}$ & $\begin{array}{l}\text { King (2002) Structuring Peer } \\
\text { Interaction to Promote High- } \\
\text { Level Cognitive Processing }\end{array}$ & $\begin{array}{l}\text { Specific questions are compiled } \\
\text { for the weekly Workshop } \\
\text { problems. Since leaders don't } \\
\text { get or distribute answer keys, } \\
\text { reflective questioning is one of } \\
\text { their most used tools. }\end{array}$ & $\begin{array}{l}\text { Leaders use the reflective } \\
\text { questions they compiled in } \\
\text { workshop }\end{array}$ \\
\hline $\begin{array}{l}\text { Troubleshooting } \\
\text { Difficult Situations }\end{array}$ & $\begin{array}{l}\text { Felps (2009), interview about } \\
\text { his research on "Bad Apples" } \\
\text { on This American Life (NPR) }\end{array}$ & $\begin{array}{l}\text { Students, in small groups, } \\
\text { discuss types of "bad apples" } \\
\text { and what to do about it. The } \\
\text { key is early intervention. }\end{array}$ & $\begin{array}{l}\text { "Bad Apples" are identified and } \\
\text { responded to diminish any } \\
\text { negative effects. }\end{array}$ \\
\hline Learning Styles & $\begin{array}{l}\text { Richard Felder's inventory is } \\
\text { completed }\end{array}$ & $\begin{array}{l}\text { Students compare their scores } \\
\text { to discover the wide variety of } \\
\text { learning styles. Ways to make } \\
\text { Workshops more varied are } \\
\text { discussed. }\end{array}$ & $\begin{array}{l}\text { Leaders promote different } \\
\text { learning styles in Workshops as } \\
\text { much as possible. }\end{array}$ \\
\hline Key Roles in Teams & $\begin{array}{l}\text { Parker (1990), Team Players } \\
\text { and Team Work, chapter } 3\end{array}$ & $\begin{array}{l}\text { Four small groups each } \\
\text { brainstorm ways to encourage } \\
\text { one of the four roles. The } \\
\text { results are then shared with the } \\
\text { entire group and discussed. }\end{array}$ & $\begin{array}{l}\text { Leaders identify the different } \\
\text { players in their workshop } \\
\text { groups and fill in where there } \\
\text { may be a void. }\end{array}$ \\
\hline Micro-inequities & $\begin{array}{l}\text { Derald Wing Sue YouTube } \\
\text { video on Micro-aggressions; } \\
\text { Funderberg (2005) The Little } \\
\text { Chill }\end{array}$ & $\begin{array}{l}\text { Students think about micro- } \\
\text { inequities they have } \\
\text { experienced and/or witnessed. } \\
\text { We discuss how they may } \\
\text { come up in Workshops and } \\
\text { how to limit them. }\end{array}$ & $\begin{array}{l}\text { Leaders listen for micro- } \\
\text { inequities and respond to them } \\
\text { as they occur. }\end{array}$ \\
\hline $\begin{array}{l}\text { Memory \& } \\
\text { Metacognition }\end{array}$ & $\begin{array}{l}\text { www.danielwillingham.com/art } \\
\text { icles }\end{array}$ & $\begin{array}{l}\text { Memory games used to } \\
\text { illustrate how memory works } \\
\text { and how to improve it. }\end{array}$ & $\begin{array}{l}\text { Leaders apply memory } \\
\text { principles in their Workshops. }\end{array}$ \\
\hline $\begin{array}{l}\text { Active Listening \& } \\
\text { Conflict Management }\end{array}$ & $\begin{array}{l}\text { Stone, Patton \& Heen (1999), } \\
\text { Difficult Conversations }\end{array}$ & $\begin{array}{l}\text { Students practice active } \\
\text { listening and compare it to } \\
\text { other kinds of listening } \\
\text { including interpretation, giving } \\
\text { advice and making judgments }\end{array}$ & $\begin{array}{l}\text { Leaders increase their active } \\
\text { listening while reducing other, } \\
\text { less effective, listening } \\
\text { techniques }\end{array}$ \\
\hline $\begin{array}{l}\text { Multicultural } \\
\text { Dimensions }\end{array}$ & Gladwell (2008) Outliers & $\begin{array}{l}\text { Hofstede's cultural dimensions } \\
\text { are examined by having } \\
\text { students "guess" how their own } \\
\text { culture falls on the scale and } \\
\text { compare to averages. }\end{array}$ & $\begin{array}{l}\text { Leaders consider all the } \\
\text { cultures represented in their } \\
\text { workshop according to } \\
\text { Hofstede's dimensions. }\end{array}$ \\
\hline Motivation & $\begin{array}{l}\text { Daniel Pink's YouTube video } \\
\text { based on his book Drive (2010) }\end{array}$ & $\begin{array}{l}\text { Students are introduced to the } \\
\text { three parts of Deci and Ryan's } \\
\text { Self-Determination Theory. In } \\
\text { small groups, they brainstorm } \\
\text { ways to meet one of the basic } \\
\text { needs and then share with the } \\
\text { larger group. }\end{array}$ & $\begin{array}{l}\text { Leaders are careful to make } \\
\text { sure all three components of } \\
\text { Deci and Ryan's theory are } \\
\text { being met in their Workshop. }\end{array}$ \\
\hline
\end{tabular}

Another important point about the workshop program is how we form the workshop groups. We believe that it is important for students to learn to work in diverse groups, and for leaders to learn to lead such groups. This includes diversity not only along cultural, geographic and gender dimensions, but also diversity in skills and temperaments. This is carefully taken into consideration while forming workshop groups. One of us (Dobson) 
designed a computer algorithm to partition the class into diverse workshop groups on any given set of attributes. The attributes we initially take into account include the region of the world, gender, academic history (GPA in previous business courses or GMAT scores), undergraduate major, intended business concentration, years of work, or membership in previous MBA teams or workshop groups. The algorithm forms diverse groups by equalizing the mean and variance across groups on the numerical measures, such as GPA, and equalizing the number in each group as much as possible for categorical measures such as number who plan to major in finance or the number of students from a particular country. The groupings are fine tuned to incorporate further qualitative information, where available. In this way, student leaders have the opportunity to work with very diverse groups of people.

\section{Leader Assessment and Feedback}

Effective development of leadership skills among workshop leaders requires an assessment of their performance in this role, and the provision of constructive feedback to reinforce strengths and correct mistakes. This is done through both personal reflection on the part of the leaders and feedback from their groups and peers.

\section{The Weekly Journal Assignment}

Every week, after their workshop session, student leaders are given a journal prompt. The prompt includes questions about the reading assignments, and also a question about how well the Workshop went for the week. An example is given below.

Journal prompt \#1

You've just completed your first workshop. Tell us about it. What went well and what didn't? Be as specific as possible. For example:

- Did you use an icebreaker - which one and how did it go?

- Did you set any ground rules for your workshop? What are they?

- What particular techniques did you use? For this question, specifically address your use of reflective questioning and/or modeling.

- Was anyone a problem for you? Describe. (No names please!)

- How did the students do with the workshop problem?

- Did you feel sufficiently prepared to lead the workshop? Why/why not?

- Do you feel like your group is off to a good start? Explain.

- Anything you would change?

Part of the purpose of the weekly journal is for the instructors, the learning specialist and the professor, to get feedback about the workshop session (problem difficulty and group success). The instructors never attend the workshop sessions, so the journal is our main access into how things are going. More importantly, the journal is an opportunity for leaders to reflect on their experience - what did they do that worked, or did not work, well. They may discuss in their journals difficult situations that they encountered such as difficult group dynamics or a success that they had. For example, one leader wrote: "I noticed this past week in particular that everyone in the group made a contribution at least once, which was nice." Another journal response included this comment: "I've always been very extroverted in my learning and I went through more listening this quarter. It was tough at times, but I felt I learned some new tactics for communication." The journals also provide an excellent opportunity to provide specific ideas to leaders about improving their effectiveness. Problems noted on the journals are often brought in for discussion during the following leader training session, thereby providing an opportunity for other leaders to learn through proxy, and try out some new things based on their peers' experiences.

\section{Student Feedback}

At the mid-point of each quarter, leaders distribute a short feedback questionnaire (see sample below). Surveys are anonymous and students are not required to participate. However, because students complete the 
feedback survey during the workshop, nearly everyone participates. The feedback is returned directly to the leaders and the instructors. We discuss the feedback in our weekly seminar to look for any general themes and possible improvements. Leaders return to their students the following week with a summary of the feedback, and a list of what they will do differently as a result of the feedback.

\section{Midterm Feedback Survey:}

1. Who is your Workshop leader?

Answer the following on a 1(LOWEST) - 7(HIGHEST) scale:

2. The rules and performance objectives of Workshop are clearly understood (goals).

3. The atmosphere is informal and relaxed (climate).

4. Everyone is clear about what is expected of him or her as members of the Workshop (roles).

5. Everyone participates in a team effort to solve the problems (participation).

6. The leader provides a sufficient degree of support for the Workshop members (support).

7. The members have sufficient resources to do the work (resources).

8. Workshop sessions are helpful (meetings).

Fill in a response to the following two questions:

9. What is the best part of the Workshop?

10. What could be improved?

\section{Peer Observations}

Whenever logistically possible, we also conduct leader observations. Each leader observes another leader during one workshop session. We find this peer observation to be important for several reasons. First, leaders get to observe another group and leader in action. In this way, they can observe another leadership style and learn about different techniques. Further, they can see a different set of group dynamics that may be much easier or much harder to facilitate than their own group. Finally, this experience gives them an opportunity to give and receive constructive feedback, something considered very important especially in the emerging realm of the authentic leadership literature (for example, Ilird, Morgeson and Nahrgang, 2005).

\section{ASSESSMENT OF THE LEADER TRAINING PROGRAM}

Given the general difficulty in assessing such soft-skills, no formal assessment of the effectiveness of the training program in developing leadership skills has been attempted thus far. However, at the end of each quarter, the leaders are asked to complete an opinion survey about their experience in the leader-training seminar and the workshop program. Time is given during the seminar period for the leaders to complete the end of term opinion survey thus ensuring that most leaders participate. These surveys are extensive, including questions about specific topics covered, questions about the problem material used, and general questions about the leader-training program. All ratings are based on a 1 (lowest) to 7 (highest) scale. Leaders are instructed to choose " 1 " if the topic was not useful at all or if they highly disagreed with the question and "7" if the topic was very useful or they highly agreed with the question. In quarters in which all leaders were repeat leaders, some of the questions were dropped. Further, seminar topics were modified from term to term and the survey reflected this modification.

\section{Survey Results}

Table 2 provides information on how many leaders participated each quarter, how many of the workshop leaders were repeats (they had previously been workshop leaders), and the number of completed surveys that we obtained. 
Table 2: Number of Leaders and Survey Participants

\begin{tabular}{|l|c|c|c|}
\hline \multicolumn{1}{|c|}{ Term \& Course } & \# Total Leaders & \# Repeats & \# Respondents \\
\hline Winter 2009 GBA & 8 & 0 & 8 \\
\hline Spring 2009 OMG & 9 & 0 & 8 \\
\hline Fall 2009 GBA & 10 & 4 & 5 \\
\hline Winter 2010 GBA & 9 & 1 & 8 \\
\hline Winter 2010 OMG & 11 & 5 & 7 \\
\hline Spring 2010 OMG & 9 & 8 & 6 \\
\hline Fall 2010 GBA & 16 & 1 & 14 \\
\hline Winter 2011 GBA & 6 & 6 & 5 \\
\hline Winter 2011 OMG & 12 & 0 & 12 \\
\hline Spring 2011 OMG & 7 & 7 & 7 \\
\hline
\end{tabular}

Total Surveys Collected $=80$

Table 3 provides students' average ratings of the different topics discussed in leadership seminars. Overall, students rated most of the topics high - the top score going to Reciprocal/Reflective Questioning with an average score of 6.2 out of $7(\mathrm{ST}=1.1, \mathrm{~N}=60)$ and the lowest score for Memory and Metacognition with an average score of $4.9(\mathrm{ST}=1.5, \mathrm{~N}=23)$.

Table 3: Mean Responses to Questions about Seminar Topics (Scale: $1=$ Lowest, $7=$ Highest)

\begin{tabular}{|l|c|c|c|}
\hline \multicolumn{1}{|c|}{ Topic } & Mean & N & STDEV \\
\hline The Meaning of Leadership & 5.3 & 73 & 1.1 \\
\hline Cognitive Apprenticeship & 5.4 & 73 & 1.1 \\
\hline Reflective/Reciprocal Questioning & 6.2 & 60 & 1.1 \\
\hline Troubleshooting Difficult Situations & 5.7 & 39 & 1.4 \\
\hline Learning Styles & 5.9 & 61 & 1.0 \\
\hline Midterm Feedback & 5.7 & 74 & 1.4 \\
\hline Parker Roles & 5.4 & 60 & 1.1 \\
\hline Motivation & 5.3 & 40 & 1.1 \\
\hline Memory and Metacognition & 4.9 & 23 & 1.5 \\
\hline
\end{tabular}

Questions about general leader training and support, and leader development, were of particular interest to us in terms of how the leaders perceived the value of the leader-training program. We were surprised and very pleased to learn that, quarter after quarter, leaders valued their participation in the program very highly (Table 4). Two questions in particular received overwhelmingly positive responses. For the first, I found leader training to be an important part of my educational experience at Simon (item 5), the average score was 6.2, with 74 students responding. Written comments for this question were illuminating (see sample comments that follow Table 4). Although not many leaders commented, those who did made positive comments. For this first question, for example, 17 students wrote comments. 14 of the comments were positive, 2 neutral, and one slightly negative. The second question, I have gained valuable leadership experience because of my participation in leader training (item 6), was even more positive with an average score of $6.6(n=58)$. Key aspects of the program that the leaders remarked on were that they received training and they had the opportunity to almost immediately practice what they learned. In sum, leaders highly valued that there was a feedback loop between the training, the immediate opportunity to apply it, and follow up discussion in the next week - something we think is a unique aspect of the Workshop Model.

Table 4: Mean Responses to Questions about Training and Leadership Development

\begin{tabular}{|c|c|c|c|}
\hline Question & Mean & $\mathbf{N}$ & STDEV \\
\hline 1. The training and support I was provided enabled me to run my workshop effectively. & 6.3 & 74 & 1.0 \\
\hline 2. The feedback I received was useful and helpful. & 5.9 & 67 & 1.0 \\
\hline 3. I received support on logistics and scheduling when needed. & 6.5 & 63 & 0.7 \\
\hline 4. I received adequate training in the content knowledge of the workshop problems. & 6.1 & 74 & 1.2 \\
\hline 5. I found leader training to be an important part of my educational experience at Simon. & 6.2 & 74 & 1.0 \\
\hline 6. I have gained valuable leadership experience because of my participation in leader training. & 6.6 & 58 & 0.8 \\
\hline
\end{tabular}


Sample comments from open-ended response to item \#5:

- $\quad$ It will be one of my defining experiences here at Simon.

- I I would rate it as one of the best experiences to have in Simon where-in I could interact with not only my peers, but also work closely with the faculty.

- Very useful, this I thought was better than any other leadership role at Simon. It provided me an opportunity to return to the Simon community and I learned a lot about the leadership styles and chance to manage a group of first years. Great Experience!

- $\quad$ Excellent!

- It has definitely been personally rewarding for me to be involved in the Workshop leader program...These skills will benefit me in my working life too since I now can implement them in group situations when leading projects.

- I Ifeel that it would be beneficial for everyone to go through this experience at least once...

- I really enjoyed this experience.

Sample comments from open-ended response to item \#6:

- $\quad$ One of the few chances to be defined as a leader at Simon.

- It really helped me learn how to effectively run a group.

- $\quad$...I consider it extremely valuable... I have noticed improvement in how I interact with team members and coworkers since I have been in the Workshop program.

To further test the significance of these results, we performed one sample t-tests against the midpoint of the scale for each question (Table 5). Not surprisingly, the t-tests revealed a statistically reliable difference between leader ratings and the midpoint (4) for all items. This suggests that for every question posed (both on leadership topics and the value of training), leaders rated their satisfaction overwhelmingly in the positive direction.

Table 5: T-test Results Against the Midpoint of the Scale

\begin{tabular}{|l|c|c|c|}
\hline \multicolumn{1}{|c|}{ Item } & t-statistic & N & p-value \\
\hline Leadership lessons & 10.48 & 73 & .000 \\
\hline Cognitive apprenticeship & 10.75 & 73 & .000 \\
\hline Reflective Questioning & 14.98 & 61 & .000 \\
\hline Learning Styles & 13.73 & 62 & .000 \\
\hline Memory and Metacognition & 2.33 & 23 & .031 \\
\hline Midterm feedback & 9.63 & 74 & .000 \\
\hline Parker Roles & 8.51 & 61 & .000 \\
\hline Bad Apples (group dynamics) & 7.86 & 39 & .000 \\
\hline Motivation & 6.78 & 40 & .000 \\
\hline Training \& support effective & 19.23 & 74 & .000 \\
\hline Help with logistics \& scheduling & 26.11 & 63 & .000 \\
\hline Feedback I received was helpful & 15.10 & 67 & .000 \\
\hline Important Educational Experience at Simon & 17.65 & 74 & .000 \\
\hline Valuable Leadership Experience & 23.69 & 57 & .000 \\
\hline
\end{tabular}

In addition to questions requiring a rating, we included several open-ended questions. Although we did vary this portion of the survey each term more so than other parts, one question remained constant and, from our perspective, quite informative: What advice would you give to future workshop leaders? Overall, leaders were very positive about the program and listed many and varied responses to the question. Some sample positive comments follow:

- $\quad$ Participate, participate, participate. I'm sure we've all had days where we didn't take part in the discussion, but in retrospect, I didn't get much out of those days so make sure to be engaged.

- $\quad$ The biggest thing is to keep in mind that the point is to get the people in your Workshops to understand the problem and feel like they could do it again on their own. So be wary of just lecturing or allowing one person to run with the problem and structure your feedback to the students in constructive ways.

2013 The Clute Institute http://www.cluteinstitute.com/ 
- $\quad$ Try to build a good rapport with your students from the onset. This has an enormous impact on the team atmosphere.

- $\quad$ Definitely do it! Also, make sure you are prepared to hold back in workshop because it is tempting to jump in all the time [to help].

- It is very important for the Workshop leaders to set a healthy atmosphere in the Workshop right from the start and set the right expectation from everyone. The Workshop should promote a comfortable environment for everyone to speak up and voice their opinion and should be formal enough to get the work done...It is a great learning experience for everyone involved and the leaders should use it in a constructive way. They should do justice to the Workshop by preparing their material diligently and thinking of ways to improve group dynamics.

- I really enjoyed working on the Workshops. I see this as a fun experience, not as a job. Do the readings, practice the problems in advance.

- $\quad$ Come to leader training with the readings and problem done and enjoy it! Get to know the students because that was the best part of the experience.

\section{Lessons Learned}

With each new term of using the Workshop Model we have learned ways to improve the program. For example, when we first implemented this program, the leader training seminar and accompanying workshops were not listed with the registrar. Now, although the leader-training seminar remains a no credit course, it is listed with the registrar and students see the course on their schedule and transcript. This is a positive development for a number of reasons. For us, it makes for far fewer conflicts as well as legitimizes our program more fully, making it easier to recruit good candidates for workshop leader positions. Having workshops on student schedules is also an important development. This reduces conflicts and lets students know that participation in workshops is expected.

We've also learned some important points about choosing and training leaders. We've trained second-year students and first-year students. Some students go through the leader training seminar once, some twice. Some leaders lead two workshop sessions in one term while others lead for two different terms. What we have found is that as long as a student has successfully completed the course in which they will serve as a leader and are open to learning about leadership, these other details don't matter.

In terms of running one versus two workshop sessions in the same term, there are advantages and disadvantages to each option. Having two sessions in the same term carries many benefits for the leader. For example, he or she gets to manage two completely different groups of people working on exactly the same problem set. In this way the leader gets to experience different group dynamics, access different personalities and try alternative techniques. He or she is forced to reflect on whether the difference is due to the difference in the membership of the group, the dynamics or to the lack of effectiveness of his/her leadership. In terms of logistics, it can be challenging for the program to have one leader lead two sessions simultaneously, especially if a leader is sick or needs to be away.

Finally, we have learned that it is best to hold workshops in two time slots back to back each week. For example, if we have 16 workshop groups total we will schedule a set of 8 groups at one time slot and the other set of 8 groups immediately following. This way, if one leader has two sessions they are conveniently timed back-to-back. Also, and more importantly, if a leader handling only a single group needs to miss, another leader can more easily fill in. Further, as a last resort students are able to join other workshop sessions if we are unable to secure a substitute leader in the event of an emergency (this has happened only once).

\section{CONCLUSIONS}

With the goal of improving student learning, the Workshop Model (also known as Peer-Led Team Learning) was implemented for two required first-year MBA core courses. The benefits of PLTL have been well documented in undergraduate education and we anticipated that this model would be of significant benefit to MBA first-year students as well (discussed in a separate paper). We were surprised and very encouraged to find that participating as a leader has considerable benefits for MBA students who, after all, are aspiring to be leaders in 
business. Even though we offer no course credit, we still have an abundance of interest in the workshop program. Leaders rated participation in the leader training program as one of the highlights of their MBA education and they rated the workshop program highly as a way for them to gain important leadership experience. While they didn't always like the extra reading and assignments (which they had to do for no official credit), they found that when they were actively engaged in these assignments they learned the most. By and large, the MBA students were very satisfied with their experience as leaders. We attribute the training program, complete with weekly self-reflection (in the form of journals) and feedback, weekly discussion with fellow leaders, and the weekly opportunity to try out new strategies and techniques in workshops, as what makes this program unique and so satisfying to our leaders.

Logistics make it unlikely that the program will expand much more at our school, so we instead will focus our efforts on sustainability. Having workshops and the leader-training seminar built into the schedule is an important component of this effort. This is very helpful for scheduling purposes but it also provides a reference to participation on student transcripts. We hope that in the near future we will be able to grant some course credit as well. Overall, the success of this program has been very rewarding and while the effort to carry it out is sizeable, the benefits to students and leaders clearly outweigh the cost. In the future we hope to explore more fully, the value of the weekly journal for leader development. Further, we want to place more emphasis on peer observations and feedback. Finally, the impact of the workshops on learning outcomes for students will have to be explored fully.

\section{AUTHOR INFORMATION}

Gregory Dobson is an Associate Professor of Operations Management at the Simon School. Professor Dobson's research interests are in batching and scheduling and applications to health care operations. He is also interested in the interface between operations and marketing related to product line design. More recently he has become interested in applying active learning techniques in his courses. He can be reached at greg.dobson@simon.rochester.edu (Corresponding author)

Robin Frye is an Assistant Director for Workshops at the Center for Excellence in Teaching and Learning at the University of Rochester. Her background is in developmental psychology. She has published research in the areas of emotion and language development. Currently, she is concerned with leadership and active learning. She can be reached at robin.frye@ simon.rochester.edu

Ravi Mantena is a Visiting Assistant Professor of Information, Operations and Management Sciences at NYU's Stern School of Business, and until recently, was on the faculty of the Simon School at the University of Rochester. His research interests are in the economics of technology and network markets, improving decision performance, and information economics. He likes experimenting with different teaching/learning approaches and course designs with an eye towards improving student engagement and learning outcomes. He can be reached at mantena@simon.rochester.edu

\section{REFERENCES}

1. Bain, K. (2004). What the Best College Teachers Do, Cambridge, MA: Harvard University Press.

2. Bean, J. (1996). Engaging Ideas: The Professor's Guide to Integrating Writing, Thinking and Active Learning in the Classroom, San Francisco, CA: Jossey-Bass Publishers.

3. $\quad$ Bennis, W. (2009). On Becoming a Leader ( $2^{\text {nd }}$ ed.), NY, NY: Basic Books.

4. Cohen, S.G. and Bailey, D.E. (1997). What makes teams work: Group effectiveness research from the shop floor to the executive suite. Journal of Management, 23, 239-290. DOI: 10.1177/014920639702300303

5. Cyr, A-A and Anderson, N.D. (2011) Trial and Error Learning Improves Source Memory Among Young and Older Adults, Psychology and Aging. Advance Online Publication. DOI:10.1037/a00251115

6. Datar, S.M., Garvin, D.A. and Cullen, P.G. (2010). Rethinking the MBA: Business Education at a Crossroads, Boston, MA: Harvard Business Press.

7. Endrissat, N., Muller, W.R. and Kaudela-Baum, S. (2007). En route to an empirically-based understanding of authentic leadership. European Management Journal, 25(3), pp. 207-220.

DOI:10.1016/j.emj.2007.04.004 
8. $\quad$ Fink, L.D. (2002). Creating Significant Learning Experiences: An Integrated Approach to Designing College Courses, San Francisco, CA: Jossey-Bass Publishers.

9. Freeman, S., O’Connor, Parks, J.W., Cunningham, M., Hurley, D., Haak, D., Dirks, C. and Wenderoth, M.P. (2007). Prescribed active learning increases performance in introductory biology. CBE-Life Sciences Education, 6(2), pp. 132-139. DOI:10.1187/cbe.06-09-0194

10. Gafney, L. and Varma-Nelson, P. (2007). Evaluating peer-led team Learning: A study of long-term effects on former workshop peer leaders. Journal of Chemical Education, 84(3), pp. 535-539.

DOI:10.1021/ed084p535

11. Gardner, B.S. and Korth, S.J. (1998). A framework for learning in teams, Journal of Education for Business, 74(1), pp. 28-33. DOI:10.1080/08832329809601657

12. George, B. (2004). Authentic Leadership: Rediscovering the Secrets to Creating Lasting Value, San Francisco, CA: Jossey-Bass.

13. George, B., Sims, P. and Gergen, D. (2007). True North: Discover Your Authentic Leadership, San Francisco, CA:Jossey-Bass.

14. Gosser, D.K., Cracolice, M., Kampeier, J.A., Roth, V. Strozak, V. and Varma-Nelson, P. (2001). Peer-led Team Learning: A Guidebook, Upper Saddle River, NY: Prentice Hall.

15. Katzenbach, J.R., Smith, D.K. and Smith, D. (2001). The Discipline of Teams: A Mindbook-Workbook for Delivering Small Group Performance, NY, NY: John Wiley \& Sons, Inc.

16. Kornell, N, Hays, M.J. and Bjork, R.A. (2009). Unsuccessful Retrieval Attempts Enhance Subsequent learning. Journal of Experimental Psychology: Learning, Memory \& Cognition, 35(4), 989-998. DOI:10.1037/a0015729

17. Ladkin, D. and Taylor, S.S. (2010). Enacting the 'true self': Towards a theory of embodied authentic leadership. The Leadership Quarterly, 21, pp. 64-74. DOI:10.1016/j.leaqua.2009.10.005

18. Lancaster, K. and Strand, C. (2001). Using the team-learning model in a managerial accounting class: An experiment in cooperative learning. Issues in Accounting Education, 16(4), pp. 549-567.

DOI:10.2308/iace.2001.16.4.549

19. Lencioni, P. (2005). Overcoming the Five dysfunctions of a Team: Facilitator's Guide, San Francisco, CA: Pfeiffer.

20. Libarkin, J.C. and Mencke, R. (Dec 2001/Jan 2002). Students teaching students: Peer training in undergraduate education. Journal of College Science Teaching, 31(4), pp. 235-239.

21. Miglietti, C. (2002). Using cooperative small groups in introductory accounting classes: A practical approach. Journal of Education for Business, 78(2), pp. 111-115. DOI:10.1080/08832320209599707

22. Offerman, L.R. and Spiros, R.K. (2001). The science and practice of team development: Improving the link, Academy of Management Journal, 44(2), pp. 376-392. DOI:10.2307/3069462

23. Platt, T., Barber, E., Yoshinakas, A. and Roth, V. (2003). An innovative selection and training program for problem-based learning (PBL) workshop leaders in biochemistry. Biochemistry and Molecular Biology Education, 31(2), pp. 132-136. DOI:10.1002/bmb.2003.494031020171

24. Platt, T., Roth, V., and Kampmeier, J.A. (2008). Sustaining change in upper level courses: Peer-led workshops in organic chemistry and biochemistry. Chemistry Education Research and Practice, 9, pp. 144148. DOI:10.1039/B806230G

25. Prince, M. (2004). Does active learning work? A review of the research. Journal of Engineering Education, 93(3), pp. 223-231. Retrieved from http://search.proquest.com/docview/217960253?accountid=13567

26. Robbins, T.L. (1994). Meaningfulness and community in the classroom: The role of teamwork in business education. Journal of Education for Business, 69(6), pp. 312-316. DOI:10.1080/08832323.1994.10117706

27. Roche, M. (2010). Learning Authentic Leadership in New Zealand: A learner-centered methodology and evaluation. American Journal of Business Education, 3(3), pp. 71-79. Retrieved from http://search.proquest.com/docview/195912160?accountid=13567

28. Roth, V., Goldstein, E. and Marcus, G. (2001). Peer-Led Team Learning: A Handbook for Team Leaders, Upper Saddle River, NY: Prentice Hall.

29. Sawada, D., Piburn, M., Judson, E., Turley, J., Falconer, K., Benford, R. and Bloom, I. (2002). Measuring reform practices in science and mathematics classrooms: The Reformed Teaching Observation Protocol. School Science and Mathematics, 102(6), 245-253. Retrieved from http://search.proquest.com/docview/195206354?accountid=13567 
30. Shamir, B. and Eilam, G. (2005). "What's Your Story?” A life-stories approach to authentic leadership development. The Leadership Quarterly, 16, pp. 395-417. DOI:10.1016/j.leaqua.2005.03.005

31. Svinicki, M. and McKeachie, W.J. (2010). Teaching Tips: Strategies, Research and Theory for College and University Teachers $\left(13^{\text {th }}\right.$ edition), Belmont, CA: Wadsworth, Cengage Learning.

32. Tien, L., Roth, V. and Kampmeier, J.A. (2002). Implementation of a peer-led team learning instructional approach in an undergraduate organic chemistry course, Journal of Research in Science Teaching, 39(7), pp. 606-632. DOI:10.1002/tea.10038

33. Tien, L.T., Roth, V. and Kampmeier, J.A. (2004). A course to prepare peer leaders to implement a studentassisted learning method, Journal of Chemical Education, 81(9), pp. 1313-1321. DOI:10.1021/ed081p1313

34. Triesman, P.U. (1992). Studying students studying calculus: A look at the lives of minority mathematics students in college. College Mathematics Journal, 23, 362-372. Retrieved from http://search.proquest.com/docview/203927296? accountid=13567

35. Yazici, H.J. (2005). A study of collaborative learning style and team learning performance. Education and Training, 47(2/3), pp. 216-229. Retrieved from

http://search.proquest.com/docview/237070712? accountid=13567 


\section{$\underline{\text { NOTES }}$}

